International Journal of Linguistics, Literature and Translation

ISSN: 2617-0299 (Online); ISSN: 2708-0099 (Print)

DOI: 10.32996/ijltt

Journal Homepage: www.al-kindipublisher.com/index.php/ijltt

\title{
Hedging of Cooperative Principles in Bunker of the Dead Movie
}

\author{
Laras Anindya ${ }^{1}$ (D) $\triangle$ and Romel Noverino ${ }^{2}$ (D) \\ ${ }^{12}$ Universitas Gunadarama, Indonesia \\ $\triangle$ Corresponding Author: Laras Anindya, E-mail: larasanindya83@gmail.com
}

ARTICLE INFORMATION

Received: April 11, 2021

Accepted: May 22, 2021

Volume: 4

Issue: 5

DOI: $10.32996 / i j l l t .2021 .4 .5 .17$

\section{KEYWORDS}

Hedging maxims, cooperative principle, types, Bunker of the Dead

\section{ABSTRACT}

Language is used in communication as a way to express their thoughts and feelings. Communication is how people use the message to give meaning to other people. Good communication happens when the speakers and the listeners can deliver their intended message clearly to understand each other. In communication, there is a theory called the cooperative principle. The cooperative principle is elaborated in four sub-principles or maxims. These maxims will make sure the information about the topic that is being discussed in the conversation clearer. However, some people sometimes communicate without following these maxims or violate maxims, knows as hedging maxim. This research aims to reveal the types of hedging maxims used by the characters in Bunker of the Dead movie. Grice's cooperative principle is to analyze the research. Descriptive qualitative is employed as the research method, and a movie transcript as the research data. The result of this research shows that there are three types of hedging maxims, namely hedging maxim of quality, hedging maxim of relevance and hedging maxim of manner. One of the maxims, namely hedging maxim of quantity, does not exist in the movie. The most used hedging maxim is the hedging maxim of quality.

\section{Introduction}

Language, either spoken or written, plays an essential role in human life. It is how people communicate and interact with others. According to Bloomer et al. (2005) is the means to convey messages to others (p. 79). Human use language in every kind of context, condition, or situation; it is used to express some feelings, describe some objects, or say something. It is not easy to imagine life without language because humans use language to understand and work with each other. Thus, language cannot be separated from human life since it is a means of communication.

Humans need communication as a way to express their thoughts. Communication is how people use a message to give meaning to other people. Good communication can be used to avoid misunderstanding and misinterpretation between the parties involved in a communicative situation. Communication consists of speakers and listeners. They must deliver their intended message clearly to understand each other. The speaker can guide the listener to clearly gain the messages in the conversation so the listener can comprehend the meaning in the speaker's utterances. Grice (in Yule, 1996) states that people may have a successful conversation if they fulfil the Cooperative Principle that is elaborated in four sub-principles or maxims ( $p$. 37).

There is a well-known theory in communication, namely the cooperative principle proposed by Grice (1975), which states that participants contribute in a conversation where required, at the stage at which it occurs, and each of the participants can accept the purpose of the conversation. The cooperative principle elaborates how people interact with others. The people who follow the rule of the cooperative principle in their conversation will make sure that what they say in their conversation gives more information about the topic that is being discussed in the conversation.

In order to explain the relationship between utterance and what is known from it, people can use the Grice maxims. The principle provides descriptions of the effectiveness in communication in a conversational that is acceptable in the natural situation. Maxim

$\begin{array}{lllll}\mathbf{K} & \mathbf{C} & \text { AL-KINDI CENTER } \\ \mathbf{R} & \mathbf{D} & \text { FOR RESEARCH AN }\end{array}$

$\mathbf{R}$ D FEVELOPMENT

Your gateway to world-class research

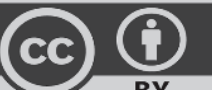

Published by Al-Kindi Center for Research and Development, London, United Kingdom. Copyright (c) the author(s). This open access article is distributed under a Creative Commons Attribution (CC-BY) 4.0 license 
of Quality, Maxim of Quantity, Maxim of Relevance, and Maxim of Manner are the four maxims. These principles can help conservation to work effectively. However, some people sometimes communicate without following these maxims.

People may violate maxims because they have their own reasons. For instance, one of the maxims proposed by Grice, particularly Maxim of Quality, expects the speaker to give the listener true information. Speakers should not say something they believe to be false or do not have the information needed about what is said or discussed. People sometimes convey more than one topic to others or sometimes doubt what they are saying because of less information. Sometimes, they are not actually certain about the information they are talking about. They put the conversation in the conversation based on what they believe or what they know. They use some words to convey what they said in order to make someone else believe to indicate that they try to keep observing the Cooperative Principle of communication. In that case, those are called by hedging maxim.

According to Lakoff (1972), a hedge is one of implicature that utterances directed and it refers to "words which are intended to make things fuzzier or less fuzzy". It is a lessening word or sound used to lessen the impact of an utterance or limiting word. Lakoff believed that any attempt to limit truth conditions for natural language sentences to true and false would make the natural language concepts to be misinterpreted by portraying them as having defined boundaries

According to Grundy (2000), hedging maxi avoids making bold statements (p. 79-80). Maxims are hedged when the information may seem informative and relevant, but in reality, it is not entirely accurate or well found. The information is usually taken from other person's opinions or what other people are saying.

Maxim hedging is an interesting topic for research. Some previous researchers already conducted this topic with many different objects. Thus, some of the previous research need to be reviewed. Mita Alfira Rosalita writes the first research (2018) entitled "Pragmatic Analysis of Hedging on English Teacher's Talk In MA Nurul Islam Tengaran" in the academic year of 2017/2018. This research is about the most dominant use of hedging by an English teacher in the learning process and the reason for the teacher's use of hedging. The researcher in this research used the teacher as a sample and the learning process in the classroom as a situation.

The second research is written by Nastiti Rokhmania (2012), entitled "Descriptive Analysis on Flouting and Hedging of Conversational Maxims In the "Post Grad" Movie". It is found that the main characters of "Post Grad" movie flout the maxims when they broke the utterances in exchanging opinion with another character by using the utterances in the form of rhetorical strategies then also hedge the maxim in their conversation. They hedge the maxim of quantity and maxim of relevance when the information in their utterances is not as precise as it might be expected nor as relevant at the stage at which it occurs.

The fact that communication is a way to express thoughts, feelings and ideas, communication is always around us. It is found in real life, but it can also be found in the dialogue of a novel, short story, drama, or movie. Movies dialogues usually represent real-life dialogue. In the movie, the characters produce utterances to make conversation with other characters. There are many movie dialogues in which contains hedges/hedging maxims. Therefore, the hedging maxim used in the movie is an interesting topic to be discussed. This research is focusing on what types of maxim hedging used in Bunker of the Dead Movie.

\section{Research Methodology}

This research focuses on the hedging maxims that occur in a particular movie used as an object in this research. In order to gather and analyze the data, the researcher employs the descriptive qualitative method. Arikunto (1998) believes that "descriptive research is conducted by describing an event of the social phenomena" (p.12). This research is descriptive because the researcher describes the phenomenon of the hedging maxim found in the research. In their statement, Heigham \& Choker (2009) say that "qualitative research places emphasize on collecting textual data and examining it using interpretative analysis", which means that this research is focused on examining and interpreting the data. In addition, Lodico (2006) defines qualitative research as a study of social phenomena in a naturalistic setting that involves observation and interview in collecting data, and the results are reported in narrative form (p. 264). Therefore, the description of qualitative research entails presenting the facts of the case in everyday language.

The data used in this research is selected from a movie entitled Bunker of the Dead. The data taken in this research is from the characters' utterances in Bunker of the Dead movie. The movie was released in 2016, directed by Matthias Olof Eich. This movie is also written by Matthias Olof Eich and Bernd Strack. This movie centres on an adventure of two friends from Bavarian town of Oberammergau, Markus and Thomas, who are following the instructions written in an old Jewish diary to gain access to a World War II underground military base formerly codenamed "CERUSIT". It is very interesting to analyze what maxims are hedged in this movie. 


\section{Result and Discussion}

A hedge is an expression of a speaker in their utterance to show that they are aware of maxims of Cooperative Principles but not thoroughly observing it. A speaker commonly uses a hedge to insinuate the possibility that their utterance may not be totally true, tell that some utterances are not quite connected to the previous one, and show that they are trying to observe maxims of Cooperative Principles. According to Grice (1975) there are four maxims: maxim of quality, maxim of quantity, maxim of relevance and maxim of manners.

\subsection{Hedging Maxim of Quality}

Using hedging maxim of quality means that the speaker is not sure whether the information that he/she has is true or not. Thus, they need an additional phrase to be aware the hearer that they will not take any responsibilities of the information that they have is true or not. Thus, the hearer cannot take it as truthful information. Below is the hedging maxim of quantity used by Markus as he arrived at the secret fence, which is an underground military base entrance.

Markus: "Hey Bubba, I found the inner fence."

Thomas: "Are you sure it's the right one?"

Markus: "I think so, it looks right"

(06:36 - 06:40)

When Thomas asks Markus if he is sure that the fence, he found is the right fence to enter the underground military base, Markus uses the word "think" to make Thomas aware that Markus himself is not totally sure whether it is the right fence or not. In the conversation above, Markus is arriving at the secret fence. Before he crosses that fence to enter the military base, he informs that he has found the fence to Thomas waiting in the car in the front gate. They are connected with their communication device, and they both have cameras so they can still see each other on the device they are using.

Another hedging maxim of quality used in Bunker of the Dead movie can be seen in the conversation below:

Markus: "Hey, how much can we get for this gold on eBay?"

Thomas: "Two, three hundred bucks, maybe."

$(19: 24-19: 29)$

In the conversation above, Thomas adds the word "maybe" at the end of his answer when Markus asks him about how much money they could get if they sell a bar of gold on e-commerce called eBay. Thomas is not entirely sure about the price point of a gold bar. Therefore, he uses the word "maybe" Thomas is using hedging maxim of quality. Markus risks his life to explore a former World War II underground military base because he wants to find gold. There, he finally found a bar of fine gold and he asks Thomas about the price point of that gold.

Another scene in which the conversation contains hedging of maxim quality is shown below:

Markus: "Oh come on, stop it! Please turn it off!"

Debby: "No way, no use in trying. Getting out isn't very likely now is it?"

$(53: 40-53: 53)$

Debby uses the word "likely" in her utterance in the conversation above. Debby is part of the United States military team who was sent to do a secret mission in that abandoned underground military base. Their plan is to blow up the whole place with a mini bomb set in auto mode to kill all the zombies down there. Unfortunately, her teams are all dead and she has stuck there alone with Markus, who happened to be there for a search of gold. The mission has failed because they could not get out of that place on time. The military team outside locked the only way out she knows. There might be a chance of getting out before the bomb explodes, but at that moment, Debby is ready to give up and accepts that she will probably die down there.

\subsection{Hedging Maxim of Relevance}

When the speaker knows that what they are saying is not relevant to the previous utterance, the maxim of relevance is considered hedged. Thus, when they want to move to another topic unrelated to the previous one, they let the hearer know by adding a kind of phrase before their utterance. Markus uses the hedging maxim of relation in the conversation below:

Markus: "Bats? I hate bats... Hey, by the way, how do you think we could get all the gold out?"

Thomas: "Uhm... let's just find it first."

$(16: 31-16: 49)$

The conversation above shows that Markus uses hedging maxim of relevance in his utterance by adding the phrase "by the way". The conversation above takes place when Markus is about to go deeper into the underground military and he hears a weird 
sound and he asks his friend Thomas if he can hear it too from the device. Thomas replies that it is probably a sound of bats. Markus dislikes bats, and he does not want to talk about it anymore and wants to change the topic of their conversation. Thus, he uses hedging maxim of relevance to talk about gold which does not relate to their topic before.

Another scene from the movie that shows maxim of relevance is hedged is in the following conversation:

Markus: "Did you say the US army didn't know about this place?"

Thomas: "Uhh... yeah."

Markus: "Tell me again."

Thomas: "No, I won't. Anyway, the main hanger should be in this area of the plant."

(28:20-28:33)

As seen above, the maxim of relevance is hedged by Thomas. Before they left Thomas' house, Thomas informs Markus that the United States military never heard of nor discover the World War II underground military base. However, Markus finds a clue that proves the US military has been down there before him. Markus shows the sign to Thomas from the camera and asks Thomas to tell him about the US army once again. Thomas refuses it and uses "anyway" in his utterance to change the subject of the conversation.

The last conversation that shows hedging maxim of relevance in the Bunker of the Dead movie is as presented below:

Markus: "By the way, did I tell you that I love women in uniform?"

Debby: "When this is over, I'll tuck it in."

(57:09-57:12)

In the conversation above, Markus uses "by the way" in his utterance. After Markus and Debby, a part of the US military team, the conversation takes place, shoot zombies together. They both panic but managed to exchange conversation for alerting each other about the position of the zombies coming closer to get them. The situation there is so intense, but they finally kill and shoot all of the nearest zombies. To calm the nerve, Markus teases Debby by stating that he loves seeing women wearing a uniform. Markus uses the hedging maxim of relevance because stating that he loves women in uniform does not have any relation to the conversation about zombies.

\subsection{Hedging Maxim of Manner}

Hedging maxim of manner is done when the speaker tries to say something that is cannot be heard clearly enough to the hearer. They add some kind of phrase so that the hearer could comprehend the content or can understand what is being talked about. Below is maxim hedging which occurs only once in Bunker of the Dead movie:

Markus: "Hey, come on, we both know you're not down here for me."

US Soldier: "That's spirit, boy, I like that. Well, you know it's a top-secret and all but, uhh... they said we'll find this thing in some sort of carrying container when we got here that thing was empty, and man... the sergeant was pissed."

(41:11-41:27)

As presented, it can be seen that a US soldier is using hedging maxim of the manner in his utterance by saying, "...you know it's a top-secret and all, but...". The conversation above occurs when Markus is running away from zombies; he accidentally runs into a group of US military soldiers hiding from the zombies. They immediately capture Markus and handcuff him. Markus asks few questions to one of them. He then answers Markus' question and uses hedging maxim of manner while answering, to emphasize that what the US military does down there is a secret, but he explains their mission to Markus anyway.

\section{Conclusion}

This research aims to reveal the types of hedging maxims used by the characters in Bunker of the Dead movie. The researcher finds three types of maxims hedged in Bunker of the Dead movie. The most hedging maxims that occur is the hedging maxim of quality. It occurs 13 times in the movie. The second type of hedging is the hedging maxim of relation, which occurs 3 times. The least type of hedging that occurs is hedging maxim of manner, which only occurs once. The researcher does not find hedging maxim of quantity in the movie. This research is expected to add the current studies related to maxims, especially hedging maxim. This research is expected to be useful for the students to use the result of the research as a learning material and useful for the lecturers as additional information to help them teach, especially in teaching about maxim. The researcher hopes this research can be explored and help conduct further research in the future. Furthermore, the researcher suggests that future researchers do research relating to maxim.

\section{References}


[1] Arikunto, S. (1998). Prosuder Penelitian Suatu Pendekatan Praktek. Jakarta: PT. Rineka Cipta.

[2] Bloomer, A., Griffiths, P., \& Mer, A. J. (2005). Introducing Language in Use: A Coursebook. London: Routledge.

[3] Grice, P. (1975). Logic and Conversation. London: Harvard University Press.

[4] Grundy, P. (2000). Doing Pragmatics. London: Arnold, a member of the Hodder Headline Group.

[5] Heigham, J., \& Choker, R. (2009). Qualitative Research in Applied Linguistics: A Practical Introduction. Hampshire: Palgrave Macmillan.

[6] Lakoff, G. (1972). Hedges: A Study in Meaning Criteria and the Logic of Fuzzy Concepts. Papers from the Eighth Regional Meeting of the Chicago Linguistic Society.

[7] Lodico, M. G. (2006). Methods in Educational Research: From Theory to Practice. USA: A Wiley Imprint.

[8] Yule, G. (1988). Discourse Analysis. Cambridge: Cambridge University Press. 